\title{
How it came about
}

Albert Starr, MD

From the Providence St Vincent Medical Center, Providence Health System, Portland, Ore.

*First appeared in the John Jones Surgical Society Newsletter, the Alumni News of the New York-Presbyterian Hospital/Columbia University Department of Surgery, Volume 10, Number 2, Fall 2007.

Received for publication Feb 13, 2008; accepted for publication Feb 17, 2008.

Address for reprints: Albert Starr, MD, 9155 SW Barnes Rd Suite 240, Portland, OR 97225 (E-mail: astarr@starrwood.com).

J Thorac Cardiovasc Surg 2008;135:1198200

$0022-5223 / \$ 34.00$

Copyright $\odot 2008$ by The American Association for Thoracic Surgery

doi:10.1016/j.jtcvs.2008.02.024
$\mathrm{M}$ uch in life is determined by being in the right place at the right time, while being prepared and bold enough to seek and seize opportunities as they present. As has been noted, I was prepared, in large part, within the Columbia system. A surgical internship interlude at John Hopkins with the great Alfred Blalock provided a little southern cover for my northeast background. I attribute my boldness to my parents and great teachers: Lionel Trilling in my undergraduate years and George Humphreys, Bob Wylie, Frank Berry, and master surgeon J. Maxwell Chamberlain at $\mathrm{P} \& \mathrm{~S}$, both as a student and during my postgraduate training. I arrived at the right place and the right time in August 1957. The University of Oregon Medical School had a brand new University Hospital with a frontier mentality and was ripe for starting a program in cardiac surgery. I met this setting with complete confidence that I could do anything, a characteristic often found among well-trained young surgeons.

The major focus of cardiac surgery then was on the treatment of congenital heart disease. Extracardiac approaches for patent ductus arteriosus, aortic coarctation, and the Blalock-Taussig shunt were well established, and the first open-heart procedure using the heart-lung machine had been performed by Gibbon in 1953. ${ }^{1}$ Lillehei and Varco in Minneapolis and Kirklin in Rochester, Minnesota, were moving swiftly. My marching orders from our Chairman, J. Englebert Dunphy, were to introduce their techniques and achieve results comparable with theirs as soon as possible. We opened an animal laboratory in 1957 for research and team training and operated on our first patient in the spring of 1958. The operating room was now our laboratory, and I became fully engaged in clinical work.

Around this time, M. Lowell Edwards visited me to ask whether I would collaborate with him in the development of an artificial heart. I told him it was too soon: we did not even have satisfactory artificial valves, and both closed and open-heart procedures on native valves were woefully crude. He was a "retired" hydraulic engineer who held 63 patents covering a variety of things, including hydraulic lumber-debarking systems and a particularly rewarding one for a fuel injection system for rapidly climbing World War II aircraft. They were providing royalty income to support his Edwards Development Laboratory in Portland, where his interests in fluid dynamics were now directed to the human circulation. We struck a deal to start the project by developing one valve at a time, taking the mitral valve first. We shook hands. In the west, that was it. He was fragile, with early Parkinson's disease, and wore crumpled slacks, a sports shirt without a tie, and a tan golfing jacket. I did not realize then that Edwards would set a grueling pace and that I was taking on an additional full-time job.

\section{Early Animal Studies}

The mitral valve is attached circumferentially to its annulus and tethered by a papillary muscle apparatus that is attached to its free edges and based in the apical portion of the left ventricle. Edwards and I made our first assumption that the tethering and a contracting mitral annulus were not essential features we had to mimic. Our first design had a single-layer sewing ring of Dacron cloth attached between 2 bonded Teflon rings with paired hemicircular, relatively thick Silastic leaflets hinged on a crossbar, retrospectively, a crude overbuilt prototype of today's bileaflet mechanical valves. Most dogs survived the operation with good cardiac function, but all died within 2 to 3 days from pulmonary edema. Autopsies showed thrombotic occlusion of the valve and areas of dehiscence around the sewing ring. A thicker, more compliant 
sewing ring greatly decreased periprosthetic leaks in the next iteration, which also had better flow washing of its hinges, but thrombosis still killed the animals in 2 to 3 days.

Lowell and I decided to abandon the leaflet design and turned our thoughts to a ball occluder with the hope that thrombus, which we knew always formed first in injured tissue, would stop at the margin of the valve orifice and not affect a well-washed ball. Ball valves were common in industry and had a little medical history. Hufnagel and colleagues ${ }^{2}$ had developed a device to palliate aortic regurgitation, consisting of a captive ball within an acrylic tube that could be rapidly inserted into the descending aorta, with spiked rings at both ends to hold the tube in place. The rigid ring and thick sewing-ring platform that we had developed was readily adaptable to restrain the ball in the closed position and to carry a flow-through cage to limit its forward excursion (Figure 1).

The concept required complete re-engineering to optimize ball-to-orifice diameters, ball travel, cage and ball materials, and many fabrication issues, but within just 3 weeks, Lowell delivered an implantable device. This new design had a dramatic short-term effect on animal survival, lengthening it to 3 to 4 weeks, when, again, all died of thrombotic occlusion except for 1 beautiful black Labrador retriever. Autopsies of the others showed massive thrombus piled up on the sewing ring and finally reaching such thickness that it could fall into the orifice, producing sudden obstruction. The surviving animal remained healthy and happy and was adopted by one of our team, which helped keep the project alive.

In the spring of 1959 , as I bounded up the stairs, the cherry blossoms caught my eye, my mind wandered, and suddenly I thought of the solution to the thrombosis problem. Why not have a Silastic shield that could be retracted during implantation and then snapped into place covering the entire zone of tissue injury? We instigated the shield, along with refinements in the cage and sewing-ring design, and produced $80 \%$ long-term animal survival, with no early deaths from thrombosis. We were on the right track at last. We could follow these animals for a few years, measuring prosthetic valvular function and looking for specific late complications, such as valve dehiscence, valve durability, hemolytic anemia, infection, and others that could not be anticipated.

\section{Animals to Human Subjects}

Dr Herbert Griswold, Oregon's Chief of Cardiology, visited the laboratory early in the summer of 1960 and was amazed to find a kennel full of healthy dogs with prosthetic mitral valves clicking away. He had many patients in the hospital in the terminal stages of heart failure with mitral valve disease and urged us to change our plan to early human implantation. Dunphy said, "Do it." We were suddenly thrust into the real world of informed consent, liability, and the need to separate manufacturing from scientific assessment, with the first potential patients already in the hospital. We selected the unshielded acrylic ball valve for the first clinical implant, the logic being to use the simpler device first; should it fail, we had the shielded valve as a backup. Were we to have used the shielded valve first and it worked, we would have been committed to the shield without knowing whether it was necessary with long-term anticoagulation and the human subject's less aggressive clotting mechanism.

Selecting patients who had no alternative therapy and a limited life expectancy of weeks or months without treatment mitigated the ethical hurdle, as did separating the business from the university's interests. Lowell and 3 other investors formed Edwards Laboratories, to be based in southern California, to manufacture artificial heart valves for human use, the first such company in the world. I remained in Oregon to continue the project as a consultant to Edwards Laboratories but with no financial interest in the company that could potentially discredit our findings, a decision I have never regretted.
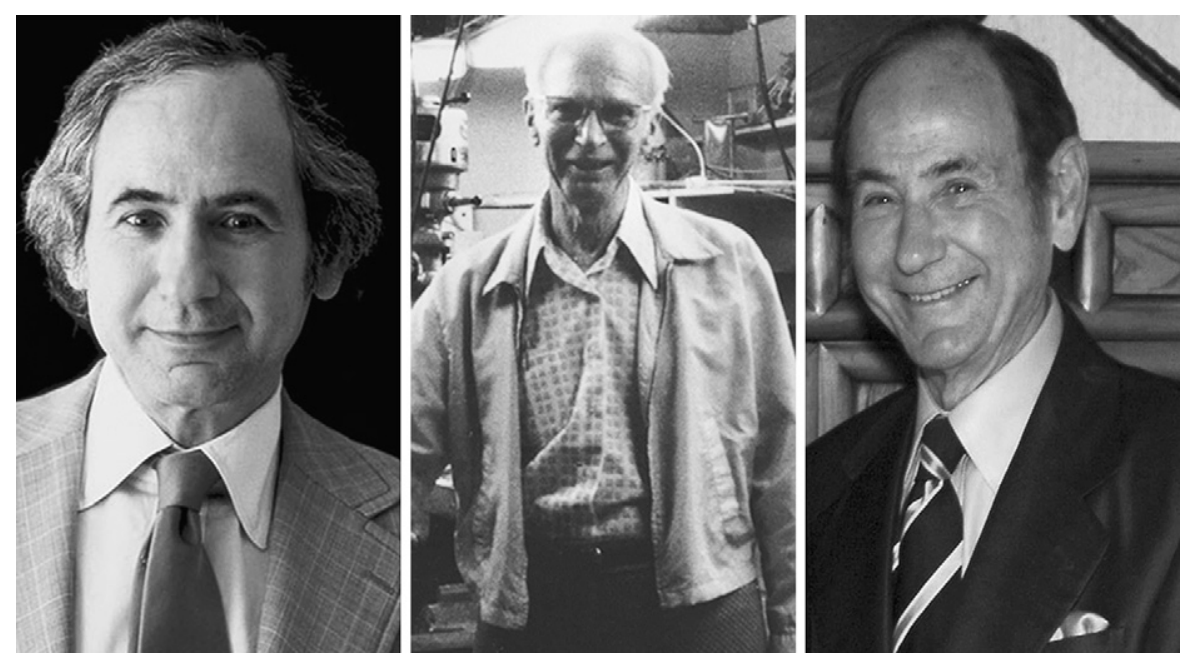

Figure 1. Albert Starr and M. Lowell Edwards, circa 1961, and Starr in his office in 2007. 


\section{The Human Experience}

The first patient was operated on in August 1960, a young woman in her late $40 \mathrm{~s}$ who was confined to the hospital with end-stage rheumatic mitral valve disease after 2 previous attempts to repair her valve. The operation was easier than in the animal laboratory, and she awakened from anesthesia in the late afternoon with excellent circulation parameters. That evening, I helped sit the patient up for a portable chest radiograph. There was an air-fluid level in the right pleural space that we interpreted as a small hemopneumothorax, but it was actually air in her massive left atrium and caused a fatal stroke when she was turned on her right side. I would never let that happen again. The second patient was a truck dispatcher, who had previously had 2 closed commissurotomies for calcific mitral stenosis. He was our first survivor. Fortunately, others followed. ${ }^{3,4}$ Valve replacement was to become a frequently performed procedure and rapidly extended to the aortic and tricuspid valves. For the first 2 decades, mechanical valves prevailed, which all required long-term anticoagulation, with its attendant bleeding problems and an occasional valve thrombosis. In the mid-1990s, the persistence of Alain Carpentier ${ }^{5}$ yielded a durable bovine pericardium valve that, in common with other tissue valves, does not require anticoagulation and is not subject to thrombotic occlusion. His valve currently is the best choice for prosthetic replacement, except in very young individuals.

\section{Looking Forward}

The future of valve surgery remains bright, with increasing acceptance of mitral repair and valve-sparing aortic root replacement. For valve replacement, the catheter-based technologies are already here, and waiting in the wings is nanotechnology blended with living autologous surfaces. We have come a long way from the war zone of the 1960s.

\section{References}

1. Gibbon JH Jr. Application of a mechanical heart and lung apparatus to cardiac surgery. Minn Med. 1954;7:171-85.

2. Hufnagel CA, Villegas PD, Nahas H. Experiences with new types of aortic valvular prostheses. Ann Surg. 1958;147:636-44.

3. Starr A, Edwards ML. Mitral replacement: clinical experience with ball valve prosthesis. Ann Surg. 1961;154:726-40.

4. Grunkemeier GL, Starr A. Twenty-five year experience with StarrEdwards heart valves: follow-up methods and results. Can J Cardiol. 1988;4:381-5.

5. Carpentier A. The surprising rise of nonthrombogenic valvular surgery. Nat Med. 2007;13:1165-8. 